\title{
RELACIJE BRAČNOG ZADOVOLJSTVA I STRATEGIJA SUOČAVANJA SA STRESOM ${ }^{1}$
}

\begin{abstract}
U radu su prikazani rezultati istraživanja koje odgovara na pitanje kako je 14 strategija suočavanja sa stresom (merenih skalom Brief COPE (Carver, 1997)) povezano sa bračnim zadovoljstvom (merenim dimenzijom Dijadnog zadovoljstva iz DAS skale (Dyadic Adjustment Scale - DAS: Spanier, 1976; 1989)), na populaciji žena koje žive u Srbiji. Pored toga, istraživanjem je utvrđena i struktura razlika u izboru strategija suočavanja sa stresom između žena koje su globalno zadovoljne svojim bračnim odnosom i žena koje su globalno nezadovoljne svojim bračnim odnosom. Među ispitanim strategijama suočavanja sa stresom, kao samostalno najznačajniji prediktor dijadnog zadovoljstva, kod žena u našoj sredini, pokazalo se korišćenje emocionalne podrške drugih ljudi. Nalazi istraživanja pokazuju da je, u proseku, za žene koje su globalno nezadovoljne svojim bračnim odnosom karakterističnije pasivno-depresivno reagovanje pri suočavanju sa stresom, dok je ženama koje su globalno zadovoljne svojim bračnim odnosom svojstvenije planiranje kako prevazići postojeći životni problem, uz oslanjanje na emocionalnu podršku drugih ljudi.

Ključne reči: brak, bračni odnosi, bračno zadovoljstvo, strategije suočavanja sa stresom.
\end{abstract}

\section{UVOD}

Bračno zadovoljstvo predstavlja subjektivnu evaluaciju pojedinaca o kvalitetu njihovog braka (Li \& Fung, 2011). Nalazi različitih istraživanja su pokazali da ono značajno utiče na emocionalnu klimu veze, utiče na ocene specifičnih aspekata braka (Hawkins, Carrere \& Gottman, 2002; Šakotić-Kurbalija i Kurbalija, 2012), na bračnu stabilnost (Šakotić-Kurbalija, 2011; Whisman, 1997), ali i na opšte zadovoljstvo životom (Felmlee, Sprecher, \& Bassin, 1990)².

Kako su savremene analize braka usmerene na identifikaciju faktora rizika za javljanje nepovoljnih bračnih ishoda (u cilju poboljšanju preventivnih intervencija), a imajući u vidu nalaze o značajnoj povezanosti bračnog zadovoljstva sa bračnom

$1 \quad$ Jelena Šakotić-Kurbalija, e-mail: jelenasakotickurbalija@gmail.com

Istraživanje prikazano ovim radom predstavlja deo projekta „Efekti egzistencijalne nesigurnosti na pojedinca i porodicu u Srbiji“, koji finansira Ministarstvo prosvete i nauke Republike Srbije (DN 179022).

2 Rezultati nekih istraživanja, međutim, ukazuju da se značajna pozitivna korelacija između bračnog zadovoljstva i opšteg subjektivnog blagostanja, može utvrditi kod žena, ali ne i kod muškaraca (Cohen, Geron \& Farchi, 2009). 
stabilnošću i globalnim životnim zadovoljstvom, pokrenuta su i brojna istraživanja u cilju utvrđivanja faktora koji doprinose bračnom zadovoljstvu. Pri tom se svi ispitivani faktori mogu razvrstati u tri grupe; to su: intrapersonalni činioci (osobine samih partnera), interpersonalni činioci (karakteristike relacije među partnerima) i sredinski činioci. Ustanovljeno je da prve dve grupe činilaca (karakteristike ličnosti partnera i katakteristike njihovog odnosa) imaju ulogu moderatora - utiču na intenzitet i smer relacije između sredinskih činilaca i zadovoljstva bračnim odnosom (Whisman, 1997).

Jedan od značajnih sredinskih činilaca predstavlja stres. Rezultati različitih istraživanja su pokazali da on vremenom dovodi do pada u zadovoljstvu brakom i do bračne nestabilnosti (Cohan \& Bradbury, 1997; Harper, Schalje \& Sandberg, 2000). Pri tom je ustanovljeno da veći uticaj na pad bračnog zadovoljstva imaju svakodnevni mikrostresori, nego pojedinačni stresni životni događaji (Bodenmann, Lederman \& Bradbury, 2007). Longitudinalna studija Bodenmann-a i Cine (2006, prema Bodenmann et al., 2007) ukazuje da su svakodnevni stresori među najvažnijim prediktorima razvoda.

Nalazi većeg broja studija, takođe, ukazuju na značajan uticaj finansijske nestabilnosti, odnosno ekonomskog stresa, na kvalitet bračnog odnosa, smanjenje bračnog zadovoljstva, bračnu nestabilnost i razvod (Burstein, 2007; Hoffman \& Duncan, 1995; Kalmijn, Loeve \& Manting, 2007; Lewin, 2005; South, 2001; S̆akotić-Kurbalija i Kurbalija, 2011; Šakotić-Kurbalija, Mihić i Kurbalija, 2012).

Rezultati preduzetih studija, takođe, sugerišu da su uzročnici raspada bračnih odnosa često nevešti pokušaji rešavanja bračnih problema (Fincham \& Beach, 1999; 2010). Razni autori su uočili povezanost kvaliteta bračnog odnosa i ishoda prevladavanja stresa (npr. Bouchard, Sabourin, Lussier, Wright \& Richer, 1998; Bowman, 1990; Cohan \& Bradbury, 1994;1997; Houser, Konstam, \& Ham, 1990; Ptacek \& Dodge, 1995; Sabourin, Laporte, \& Wright, 1990), te su brojna istraživanja preduzeta s ciljem da se utvrdi kako su strategije suočavanja sa stresom povezane sa kvalitetom bračnog odnosa i bračnim zadovoljstvom.

Ustanovljeno je da je izbegavanje problema u negativnoj korelaciji sa bračnim zadovoljstvom; da su usmerenost na emocije i bračno zadovoljstvo u pozitivnoj korelaciji; dok usmerenost na rešavanje problema nije značajno povezana sa bračnim zadovoljstvom (Bowman, 1990). Neki autori su utvrdili da optimistična poređenja i pregovori pozitivno utiču na doživljaj bračnog zadovoljstva, a da odustajanje i selektivno ignorisanje ponašanja negativno utiču na bračno zadovoljstvo (Sabourin et al., 1990).

Ustanovljeno je, takođe, da muškarci i žene pribegavaju različitim strategijama kada se suočavaju sa bračnim problemima (Bouchard et al., 1998; Hobfoll, Dunahoo, Ben-Porath, \& Monnier, 1994). Dok muškarce u većoj meri karakteriše kompetitivno ponašanje i orijentisanost na zadatak, za žene je utvrđeno da se $u$ većoj meri ponašaju prosocijalno, asertivno i empatično, $u$ interpersonalnom domenu. Nalazi ovih istraživanja pokazuju da žene izveštavaju o većoj brizi, konfliktima i traženju drugih aktivnosti van braka, kako bi odgovorile zahtevima 
koje stvaraju bračni problemi. Pri tom, žene koje prevazilaze stres koristeći ove strategije pokazuju manje bračno zadovoljstvo, iako njihova upotreba predstavlja aktivan napor čija je svrha zaboravljanje teškoća prouzrokovanih stresorom (Hobfoll, et al., 1994). Neki autori (Bouchard et al., 1998) smatraju da žene mogu imati kratkoročne benefite od korišćenja strategije poricanja, a do sličnog nalaza se došlo i istraživanjem u našoj sredini, kada je ustanovljeno da je bračno zadovoljstvo žena u pozitivnoj korelaciji sa sklonošću ka poricanju postojanja problema (Šakotić-Kurbalija, 2011).

Uzimajući u obzir najkonzistentnije rezultate istraživanja u ovoj oblasti (Bi1lings \& Moos, 1981; Hamilton \& Fagot 1988; Stone \& Neale, 1984), suočavanje sa stresom kod žena može se opisati kao pribegavanje emocionalnim odgovorima na probleme i provođenje vremena u diskusiji sa prijateljima ili porodicom o problemima, što kao posledicu najčešće ima percepciju visokog zadovoljstva bračnim odnosom; kao i korišćenje različitih ponašanja izbegavanja i udaljavanja od problema, što kao ishod najčešće ima doživljaj niskog bračnog zadovoljstva.

U skladu sa napred navedenim nalazima su i rezultati istraživanja dobijeni u našoj sredini, u okviru Projekta „Efekti egzistencijalne nesigurnosti na pojedinca i porodicu u Srbiji” (Miljanović, Šakotić-Kurbalija i Kurbalija, 2013; ŠakotićKurbalija, 2011). U jednom od ovih radova (Šakotić-Kurbalija, 2011), zaključeno je da je visok stepen zadovoljstva brakom, kod žena, pre svega povezan sa samoprocenom efikasnosti u rešavanju bračnih konflikata, kumulativnom sumom stresa koji potiče od pozitivnih životnih događaja (percipiraju da imaju puno pozitivnih, a veoma malo ili nimalo negativnih životnih događaja), traženjem emocionalne podrške i razumevanja u stresnim situacijama, ali i sklonošću ka negiranju postojanja problema; a da je bračno nezadovoljstvo povezano sa doživljajem veće lične vrednosti u odnosu na partnera, izraženim anksioznim stilom afektivne vezanosti, dužinom vremena koje je par proveo pre nego što su počeli da žive zajedno, pasivnim odnosom prema stresnim situacijama i traženjem instrumentalne podrške od drugih, kao načinom prevazilaženja stresnih situacija (od drugih ne traže razumevanje i podršku, već konkretne savete i pomoć), i kumulativnom sumom stresa koji potiče od negativnih / neugodnih životnih događaja (percipiraju da imaju dosta negativnih, a veoma malo ili nimalo pozitivnih životnih događaja).

U cilju utvrđivanja u kojoj meri različite strategije suočavanja sa stresom doprinose globalnom bračnom zadovoljstvu žena u našoj sredini, utvrđeno je da je skup analiziranih strategija suočavanja sa stresom statistički značajno povezan sa bračnim zadovoljstvom, ali da je ta povezanost relativno niska $(\mathrm{R}=0,28 ; \mathrm{p}<0,00)$. Strategije usmerene na problem se nisu pokazale kao samostalni značajan prediktor zadovoljstva brakom kod žena, dok su se strategija izbegavanja i strategija traženja (i dobijanja) podrške iz spoljašnje sredine, pokazale i kao samostalni značajni prediktori. Pri tom je zaključeno da što više žene koriste izbegavanje, kao strategiju suočavanja sa stresom, to će imati slabije izraženo bračno zadovoljstvo, a da traženje i dobijanje podrške iz spoljašnje sredine u stresnim situacijama 
ima pozitivan uticaj na globalno zadovoljstvo bračnim odnosom (Miljanović i dr., 2013).

Ovde je značajno istaći i nalaze istraživanja, takođe sprovedenih u našoj sredini, koja su, iako transferzalna, imala za cilj sagledavanje razvojne perspektive emocionalne klime, kvaliteta i stabilnosti bračnog odnosa (Jestrović, 2014; Šakotić-Kurbalija, 2013). Mada su sprovedena na različitim uzorcima ispitanika, ova istraživanja imaju potpuno usaglašene nalaze koji sugerišu negativan razvojni trend u brakovima u Srbiji. Kvalitet bračnog odnosa, a posebno zadovoljstvo brakom, konstantno opada kako se prelazi iz jednog bračnog razdoblja u drugo, od početka do kraja bračnog kontinuuma, a pri tom se povećava bračna stabilnost (Šakotić-Kurbalija, 2013).

Utvrđeno je da se najveći broj brakova sa malom decom nalazi u kategoriji „burne relacije“ (imaju visoku učestalost i pozitivnih i negativnih interakcija u paru), dok se veliki broj parova u kasnijim fazama braka nalazi u distresu - $\mathrm{u}$ hostilnim odnosima (imaju nisku pozitivnu i visoku negativna razmenu). Pri tom, muškarci procenjuju da njihove supruge ispoljavaju viši stepen pozitivnih interakcija, nego što to navode žene za svoje partnere (Jestrović, 2014).

Imajući u vidu sve napred navedene nalaze o razlikama između muškaraca i žena, ovaj rad se bavi relacijama bračnog zadovoljstva i strategija suočavanja sa stresom samo na populaciji žena u Srbiji. Istraživanjem, prikazanim ovim radom, je utvrđeno u kojoj meri različite strategije suočavanja sa stresom doprinose bračnom zadovoljstvu; a pored toga, utvrđena je i struktura razlika u korišćenju strategija suočavanja sa stresom između žena koje su globalno zadovoljne svojim bračnim odnosom i žena koje su globalno nezadovoljne svojim bračnim odnosom.

\section{METOD}

Uzorak. Ispitano je 2049 žena, starosti od 19 do 75 godina (AS=38,86; $\mathrm{SD}=8,94)$, koje žive u formalnom $(86,7 \%)$ ili neformalnom braku, između godinu dana i 52 godine ( $\mathrm{AS}=13,67$; $\mathrm{SD}=9,10)$. Njihovi partneri su stari od 22 do 82 godine $(\mathrm{AS}=41,98 ; \mathrm{SD}=9,40)$. Najveći broj ovih parova ima stan u vlasništvu $(67,7 \%)$; $15,2 \%$ stanuje kod roditelja jednog od supružnika, dok ostali žive kao podstanari. Ukupne mesečne prihode u domaćinstvu nešto manje od polovine broja ispitanica procenjuje prosečnim $(46,5 \%) ; 20,5 \%$ ispitanica ocenjuje da su im prihodi nešto iznad prosečnih; $3,7 \%$ da su im prihodi znatno iznad prosečnih, dok $16,5 \%$ ispitanica procenjuje da su im prihodi nešto ispod prosečnih, a 11,8\% ocenjuje da su prihodi njihovog domaćinstva znatno ispod prosečnih.

Nešto više od polovine ispitanica ima završenu srednju školu (53,9\%), a zatim sledi broj ispitanica koje su završile fakultet (28,7\%) i višu školu (8,7\%). Uzorkom je obuhvaćen i znatan broj žena sa poslediplomskim obrazovanjem (4\%), ali i onih koje imaju završenu samo osnovnu školu (4\%) i onih žena koje nisu završile ni osnovnu školu $(0,3 \%)$. Slično je distribuirano i obrazovanje njihovih partnera $(0,3 \%$ partnera nije završilo ni osnovnu školu, 5,6\% ima završenu osnovnu školu, 56,3\% 
srednju školu, 10,4\% višu školu; 21,2\% ih ima fakultetsko; a 3,4\% i poslediplomsko obrazovanje).

Većina ispitanica je u radnom odnosu (od toga: $11,9 \%$ na određeno vreme; $52 \%$ na neodređeno, a 6 su (su)vlasnice preduzeća); $2,9 \%$ ispitanica je u penziji, njih $13,1 \%$ se izjašnjavaju kao domaćice, dok ih $13,6 \%$ traži posao i izjašnjavaju se kao „trenutno nezaposlene”. Među njihovim partnerima ima 15,1\% nezaposlenih; $14,5 \%$ je zaposlenih na određeno, a $48,6 \%$ na neodređeno vreme; njih $14,2 \%$ su (su)vlasnici nekog preduzeća, a 4,4\% su penzioneri.

Gotovo polovina ispitanica ima dvoje dece $(46,8 \%)$, njih $24 \%$ ima jedno dete; $14,9 \%$ nemaju decu, $8,9 \%$ ima troje dece, a preostale ispitanice imaju četvoro ili više dece.

Postupak. Ispitivanje je, u saradnji sa stručnim saradnicima - psiholozima, sprovedeno na teritoriji Republike Srbije, pri čemu 46,7\% ispitanih žena živi u Novom Sadu i Beogradu, a 53,3\% u manjim mestima i selima. Najveći broj ispitanica je kontaktiran na roditeljskim sastancima u školama (osnovnim i srednjim) i vrtićima, gde im je ukratko objašnjen cilj istraživanja i predloženo anonimno učešće $u$ istraživanju, na dobrovoljnoj osnovi. Žene, koje su prihvatile učešće u istraživanju, su dobile upitnike i koverte. Odgovarale su kod kuće i popunjene upitnike vraćale vaspitačicama i razrednim starešinama u zatvorenim kovertama. Ispitivanje žena iz brakova bez dece je prvenstveno vršeno preko ginekoloških ordinacija, a u manjoj meri i putem interneta (preko različitih mailing lista i internet grupa).

Instrumenti. Za ispitivanje strategija suočavanja sa stresom, primenjena je Brief COPE skala (Carver, 1997). Skala sadrži 28 opisa različitih ponašanja u stresnim situacijama. Od ispitanika se traži da se prisete stresnih situacija koje su se dogodile u poslednjih nekoliko meseci i da označe kako procenjuju učestalost svog ponašanja na dati način, $u$ cilju prevladavanja stresa (ponuđeni odgovori su: „nikada“, „retko“, „ponekad“ i , „često“). Skala meri sledećih 14 načina suočavanja sa stresom: samoometanje, aktivno prevladavanje, poricanje, zloupotreba supstanci, emocionalna podrška, instrumentalna podrška, bihevioralno neangažovanje, ventiliranje, pozitivno redefinisanje (reinterpretacija), planiranje, humor, prihvatanje, religioznost i samookrivljivanje. Na podacima prikupljenim ovim istraživanjem, ustanovljena je zadovoljavajuća pouzdanost instrumenta merena Kronbahovim Alfa koeficijentom $(\alpha=0,85)$.

Bračno zadovoljstvo je mereno DAS subskalom Dijadno zadovoljstvo (Dyadic Adjustment Scale - DAS: Spanier, 1976; 1989), a obuhvata sledeće procene:

- stepen opšteg zadovoljstva brakom,

- učestalost razmišljanja o tome kako bi bilo biti u vezi ili braku s nekim drugim,

- učestalost završanja bračnog konflikta impulsivnim izlaskom iz kuće jednog od bračnih partnera,

- učestalost razmišljanja o tome da bračni odnos „ide dobro”,

- učestalost žaljenja zbog ulaska u brak,

- učestalost bračnih konflikata, 
- učestalost doživljaja međusobnog iritiranja bračnih partnera,

- stepen poverenja u bračnog partnera,

- učestalost ljubljenja bračnog partnera, i

- lični odnos prema budućnosti braka i stepen spremnosti na lično angažovanje u njegovom očuvanju.

Na podacima prikupljenim ovim istraživanjem, ustanovljena je zadovoljavajuća pouzdanost DAS subskale Dijadno zadovoljstvo; merena Kronbahovim Alfa koeficijentom ona iznosi 0,88 .

Globalno bračno zadovoljstvo je mereno ajtemom u kom se od ispitanica traži da „uzimajući sve u obzir”, na sedmostepenoj skali (od 1 - veoma nezadovoljna, do 7 - potpuno zadovoljna) procene koliko su, u celini, zadovoljne svojim bračnim odnosom.

U cilju utvrđivanja doprinosa različitih strategija suočavanja sa stresom bračnom zadovoljstvu, primenjena je višestruka regresiona analiza. Pri tom, skup prediktorskih varijabli čini 14 načina suočavanja sa stresom, merenih Brief COPE skalom (Carver, 1997), a kriterijsku varijablu predstavlja ukupni skor na dimenziji dijadnog zadovoljstva iz DAS skale (Dyadic Adjustment Scale - DAS: Spanier, 1976; 1989).

U cilju utvrđivanja strukture razlika u izboru strategija suočavanja sa stresom u odnosu na globalno zadovoljstvo bračnim odnosom kod žena, primenjena je diskriminativna analiza.

Kao što se može videti ispod, u tabeli 1, distribucija odgovora na skali globalnog bračnog zadovoljstva je pomerena u pravcu visokih skorova, te su u diskriminativnoj analizi grupu žena nezadovoljnih brakom svrstane sve ispitanice (ukupno 163) koje su iskazale veći stepen nezadovoljstva, u odnosu na bračno zadovoljstvo (odgovori 1, 2 i 3), dok su u grupu zadovoljnih brakom svrstane samo ispitanice (544) koje su izjavile da su potpuno zadovoljne svojim bračnim ili partnerskim odnosom (odgovor 7). Na ovaj način su diskriminativnom analizom obuhvaćeni odgovori 707 ispitanica, od ispitanih 2049.

\section{REZULTATI}

U tabeli 1 je prikazana distribucija prikupljenih odgovora ispitanica na sedmostepenoj skali globalnog bračnog zadovoljstva (raspršenje dobijenih odgovora na pitanju „Uzimajući sve u obzir, koliko ste zadovoljni Vašim bračnim ili partnerskim odnosom?"). Iz ove tabele se može videti da ima vrlo malo ispitanica koje su se izjasnile da su vrlo nezadovoljne svojim bračnim odnosom. Generalno, odgovori ispitanica o globalnom bračnom zadovoljstvu su značajno pomereni $u$ smeru iskazivanja visokog zadovoljstva. 
Tabela 1 Odgovori ispitanica na skali globalnog bračnog zadovoljstva

\begin{tabular}{lcc}
\hline Grupa & Frekvencija & Procenat \\
\hline 1. Veoma nezadovoljna & 18 & .9 \\
2. Nezadovoljna & 40 & 2.0 \\
3. Više nezadovoljna nego zadovoljna & 105 & 5.1 \\
4. Nisam sigurna (ni zadovoljna, ni nezadovoljna) & 155 & 7.6 \\
5. Više zadovoljna nego nezadovoljna & 350 & 17.1 \\
6. Prilicno zadovoljna & 820 & 40.0 \\
7. Potpuno zadovoljna & 544 & 26.5 \\
Ukupno & 2032 & 99.2 \\
\hline
\end{tabular}

Korelacija između globalnog bračnog zadovoljstva, merenog jednim ajtemom, i ukupnog skora na DAS dimenziji dijadnog zadovoljstva iznosi 0,88 . U grafikonu 1 je prikazana distribucija skorova utvrđenih DAS subskalom.

Grafikon 1. Distribucija skorova na DAS dimenziji dijadnog zadovoljstva

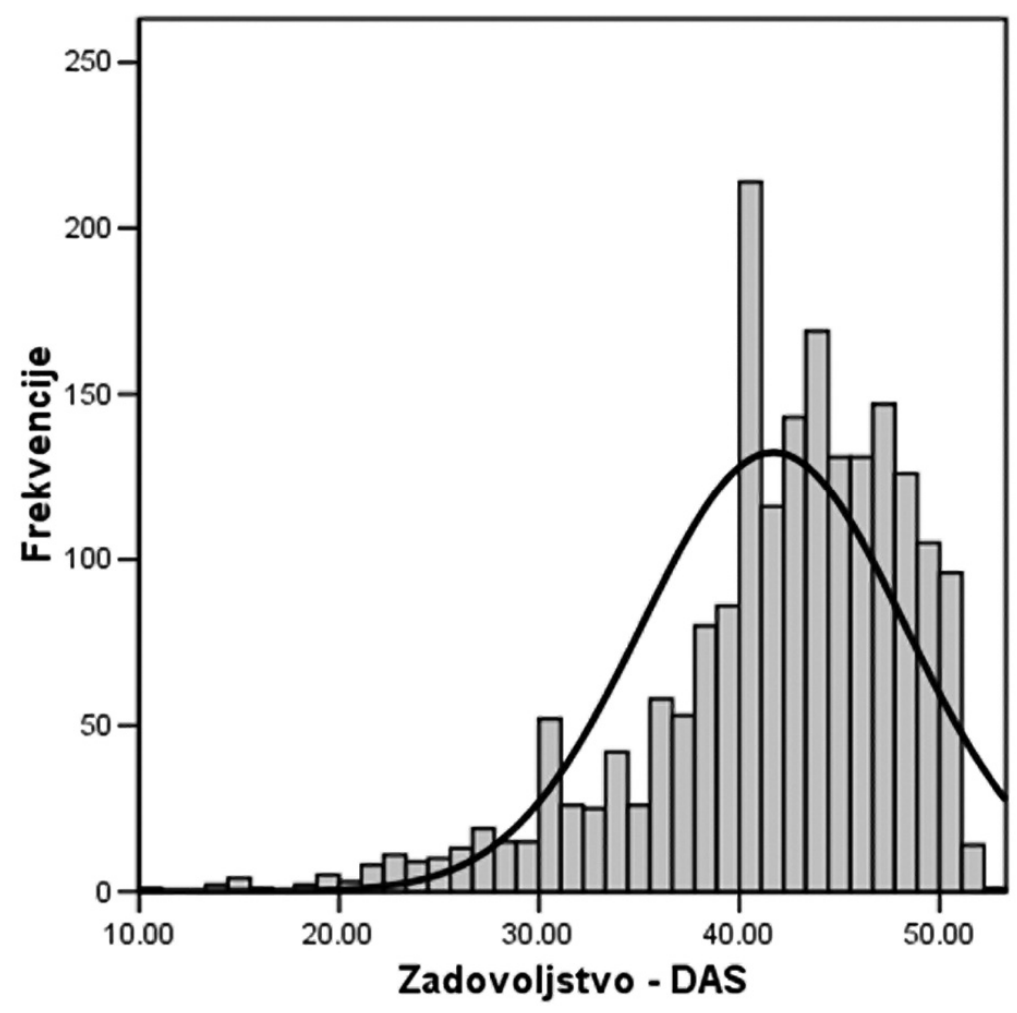


Kao što se može videti na Grafikonu 1, distribucija odgovora ispitanica na skali dijadnog zadovoljstva odstupa od normalne distribucije i pomerena je ka višim skorovima koji su grupisani oko aritmetičke sredine $\mathrm{AS}=41,70(\mathrm{SD}=6,56$; Skjunis $=-1,21$; Kurtosis $=1,65$ ). Iako se raspon odgovora ispitanica kreće od minimalnog do maksimalnog skora (10-53), na grafikonu se vidi da najveći broj njih ima rezultat između 40 i 50, što ukazuje na to da su ispitanice u proseku zadovoljne bračnim i kohabitacijskim odnosima u kojima se trenutno nalaze.

U tabeli 2 su prikazani regresioni parametri i indikatori statističke značajnosti za sve mehanizme suočavanja sa stresom, koji predstavljaju skup prediktorskih varijabli, u odnosu na dijadno zadovoljstvo mereno DAS subskalom.

Skup analiziranih prediktorskih varijabli je statistički značajno povezan sa dijadnim zadovoljstvom. Utvrđeni koeficijent multiple korelacije je $\mathrm{R}=0,46$ $(F(14,1353)=25,37 ; p<0,001)$, dok je korigovani koeficijent $R^{2}=0,21$; što govori da postoji oko $20 \%$ zajedničke varijanse.

Tabela 2 Regresioni parametri i indikatori statističke značajnosti prediktorskih varijabli

\begin{tabular}{lrrrrc}
\hline & \multicolumn{1}{c}{$\mathrm{B}$} & $\begin{array}{c}\text { St. } \\
\text { greška }\end{array}$ & Beta & $\mathrm{t}$ & $\mathrm{p}$ \\
\hline Konstanta & 42.529 & 1.251 & & 34.006 & .000 \\
Samoometanje & -1.256 & .249 & -.147 & -5.050 & .000 \\
Aktivno prevladavanje & .478 & .316 & .048 & 1.514 & .130 \\
Poricanje & -.250 & .202 & -.036 & -1.240 & .215 \\
Zloupotreba supstanci & -.613 & .246 & -.067 & -2.493 & .013 \\
Emocionalna podrška & 2.806 & .291 & .334 & 9.629 & .000 \\
Instrumentalna podrška & -.653 & .279 & -.080 & -2.343 & .019 \\
Bihejvioralno neangažovanje & -1.215 & .252 & -.140 & -4.822 & .000 \\
Ventiliranje & -.882 & .231 & -.108 & -3.820 & .000 \\
Pozitivno redefinisanje & .107 & .320 & .011 & .336 & .737 \\
(reinterpretacija) & .620 & .342 & .058 & 1.812 & .070 \\
Planiranje & .359 & .179 & .055 & 2.006 & .045 \\
Humor & -.502 & .269 & -.057 & -1.863 & .063 \\
Prihvatanje & -.154 & .167 & -.025 & -.924 & .356 \\
Religioznost & -.509 & .213 & -.066 & -2.391 & .017 \\
Samookrivljvanje. & & & & & \\
\hline
\end{tabular}

Kao što se može videti iz tabele 2, samostalno značajne prediktore dijadnog zadovoljstva predstavljaju sledeće strategije suočavanja sa stresom: korišćenje emocionalne podrške, samoometanje, bihejvioralno neangažovanje, ventiliranje, instrumentalna podrška, zloupotreba supstanci, samookrivljivanje i humor. 
U tabeli 3 su dati osnovni rezultati sprovedene diskriminativne analize u odnosu na globalno zadovoljstvo bračnim odnosom.

Tabela 3 Rezultati diskriminativne analize u odnosu na globalno bračno zadovoljstvo

\begin{tabular}{ccccccccc}
\hline $\mathrm{F}$ & $\lambda$ & $\begin{array}{c}\% \\
\text { varijanse }\end{array}$ & $\begin{array}{c}\text { Kumulativni } \\
\% \text { varijanse }\end{array}$ & $\mathrm{r}_{\mathrm{c}}$ & $\begin{array}{c}\text { Wilksova } \\
\lambda\end{array}$ & $\chi 2$ & $\mathrm{df}$ & $\mathrm{p}$ \\
\hline 1 & .386 & 100.0 & 100.0 & .528 & .722 & 201.385 & 14 & .000 \\
\hline
\end{tabular}

$\mathbf{F}$ - izolovana diskriminativna funkcija; $\boldsymbol{\lambda}$ - karakterističan koren diskriminativnog faktora; \% varijanse - procenat varijanse objašnjene diskriminativnim faktorom; $\mathbf{r}_{\mathbf{c}}-$ koeficijent kanoničke korelacije; Wilksova $\boldsymbol{\lambda}$ - mera razlika centroida grupa; $\boldsymbol{\chi 2}$ - test značajnosti Wilksove $\lambda$; $\mathbf{d f}$ - broj stepeni slobode; $\mathbf{p}$ - nivo značajnosti diskrim. funkcije.

Kao što se može videti iz tabele 3, utvrđena je statistički značajna diskriminativna dimenzija, na nivou $\mathrm{p}=0,00$. Koeficijent kanoničke korelacije iznosi $\mathrm{r}=0,53$ i upućuje na postojanje umerene izraženosti razlika među grupama, na utvrđenoj diskriminativnoj dimenziji. Izvod iz matrice strukture diskriminativnog faktora je prikazan u tabeli 4, dok je kompletna matrica strukture prikazana u tabeli 7 , u Prilogu.

Tabela 4 Izvod iz matrice strukture diskriminativnog faktora

\begin{tabular}{lc}
\hline Varijabla & Korelacija \\
\hline Bihevioralno neangažovanje & .609 \\
Emocionalna podrška & -.523 \\
Zloupotreba supstanci & .486 \\
Samookrivljivanje & .384 \\
Planiranje & -.301 \\
Ventiliranje & .300 \\
\hline
\end{tabular}

Kao što se može videti iz tabele 4, izolovani diskriminativni faktor je u najvećoj meri određen bihejvioralnim neangažovanjem, zatim emocionalnom podrškom i zloupotrebom supstanci; a u znatno manjoj meri samookrivljivanjem, planiranjem i ventiliranjem.

Pri tom, pozitivan pol diskriminativne dimenzije karakterišu odustajanje od pokušaja da se reši postojeći problem (bihejvioralno neangažovanje), doživljaj nepostojanja emocionalne podrške, utehe i razumevanja od drugih ljudi, te usmeravanje na konzumiranje alkohola ili drugih opijata (zloupotreba supstanci) praćeno okrivljivanjem sebe za nastali problem, bez ikakvog planiranja kako prevazići problem, odnosno, bez razmišljanja o koracima koji se mogu preduzeti i razvijanja bilo kakvih strategija po pitanju budućeg ponašanja u cilju prevazilaženja postojećeg problema. Negativni pol dimenzije karakteriše suprotno. Imajući u vidu sadržaj varijabli koje u najvećoj meri definišu dobijeni diskriminativni faktor, možemo pretpostaviti da pozitivan pol dimenzije predstavlja depresivno rea- 
govanje pri suočavanju sa životnim problemima, dok negativan pol karakteriše proaktivni pristup životnim problemima, uz značajno oslanjanje i na emocionalnu podršku drugih ljudi.

Dobijeni diskriminativni faktor je interpretiran kao pasivno-depresivno reagovanje pri suočavanju sa stresom nasuprot aktivnom planiranju prevazilaženja problema uz oslanjanje na emocionalnu podršku drugih ljudi.

Tabela 5. Centroidi grupa na diskriminativnom faktoru

\begin{tabular}{lc}
\hline Grupa & Centroidi \\
\hline Nezadovoljne & 1.140 \\
Zadovoljne & -.337 \\
\hline
\end{tabular}

Kao što se može videti na osnovu veličine i predznaka centroida grupa (tabela 5), prosečna vrednost na diskriminativnoj dimenziji grupe žena koje su nezadovoljne svojim bračnim odnosom je pomerena ka pozitivnom polu, dok je prosečna vrednost odgovora za žene koje su zadovoljne svojim bračnim odnosom blago pomerena ka negativnom polu diskriminativnog faktora. Raspršenje odgovora na utvrđenoj diskriminativnoj dimenziji, za poduzorke žena u odnosu na njihovo bračno zadovoljstvo, prikazano je na grafikonu 1 .

Grafikon 2. Raspršenje odgovora na diskriminativnom faktoru

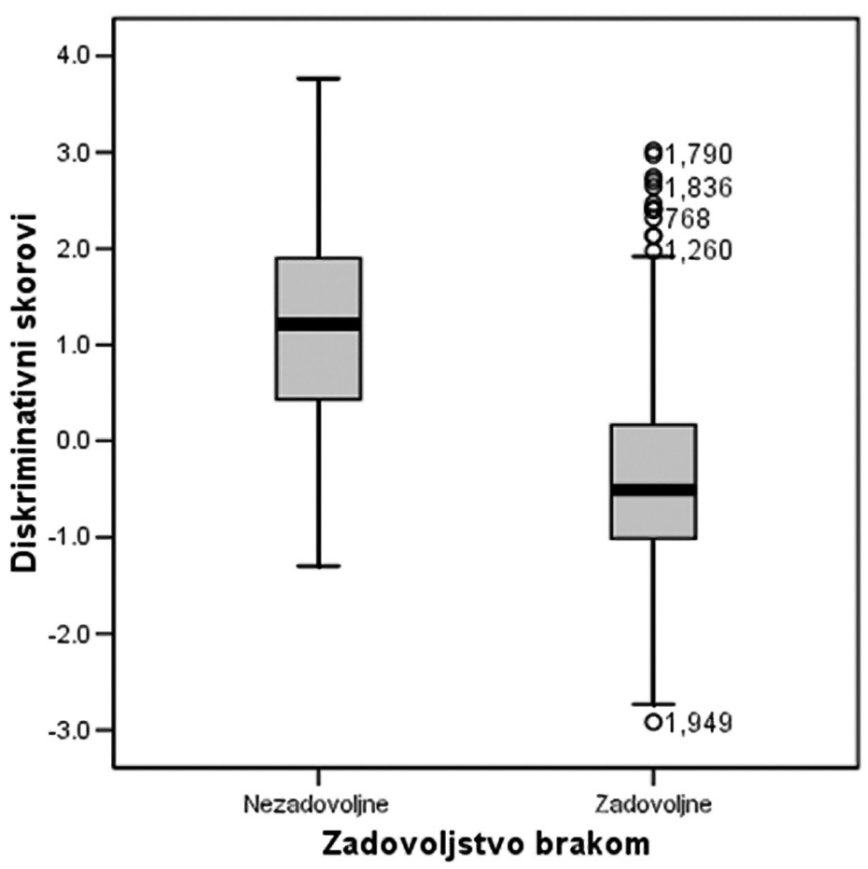


Kao što se vidi na grafikonu 2, iako postoji određeni raspon diskriminativnih skorova za obe grupe ispitanica, može se reći da je, u proseku, za žene koje su globalno nezadovoljne svojim bračnim odnosom karakterističnije pasivno-depresivno reagovanje pri suočavanju sa stresom, dok je ženama koje su globalno zadovoljne svojim bračnim odnosom svojstvenije planiranje kako prevazići postojeći životni problem, i to uz oslanjanje na emocionalnu podršku drugih ljudi.

Svakako treba biti oprezan pri uopštavanju ovih rezultata, pošto na osnovu ove diskriminativne dimenzije 20,6\% ispitanica nije ispravno klasifikovano (što se može videti u tabeli 6). U oba poduzorka pojedine ispitanice imaju izrazito niske, a pojedine ispitanice izrazito visoke diskriminativne skorove, odnosno, među ispitanim ženama koje su iskazale potpuno zadovoljstvo svojim bračnim odnosom ima žena koje ispoljavaju karakteristike suočavanja sa stresom koje su karakteristične za grupu žena koje su iskazale nezadovoljstvo svojim bračnim odnosom, i obrnuto (što se može videti na grafikonu 2).

Tabela 6. Rezultati klasifikacije odgovora na diskriminativnom faktoru

\begin{tabular}{llcc}
\hline & & $\begin{array}{c}\text { Predviđeno članstvo u grupi } \\
\text { Nezadovoljne }\end{array}$ & Zadovoljne \\
\hline Stvarne & Nezadovoljne & 107 & 36 \\
grupe & Zadovoljne & 93 & 390 \\
& Negrupisane ispitanice & 500 & 678 \\
\hline
\end{tabular}

Ispravno je klasifikovano $79.4 \%$ ispitanika.

\section{DISKUSIJA}

Na samom početku razmatranja dobijenih rezultata, značajno je primetiti da su odgovori ispitanica o globalnom bračnom zadovoljstvu značajno pomereni $\mathrm{u}$ smeru iskazivanja visokog zadovoljstva. Tako se od 2049 ispitanica, samo njih 18 izjasnilo da su vrlo nezadovoljne svojim bračnim odnosom (što je manje i od $1 \%$ ispitanih žena), a ukupno $8 \%$ žena, od onih koje su dale odgovor na ovo pitanje, je bilo spremno da iskaže bilo kakav stepen nezadovoljstva; dok je čak $66,5 \%$ ispitanica odgovorilo da su vrlo zadovoljne svojim bračnim odnosom u celini (pri tom je $40 \%$ ispitanica iskazalo prilično, a čak $26,5 \%$ potpuno zadovoljstvo bračnim odnosom). Distribucija odgovora ispitanica na skali dijadnog zadovoljstva, koja obuhvata 10 stavki, takođe odstupa od normalne distribucije, $i$ isto govori da su ispitanice u proseku vrlo zadovoljne svojim partnerskim odnosom.

Mada neka istraživanja (Hojjat, 2000) sugerišu da su žene objektivniji procenjivači konflikata u partnerskom odnosu od muškaraca, te da se njihove procene u većoj meri slažu sa procenama nezavisnih posmatrača, iskazivanje visokog globalnog i dijadnog zadovoljstva na ispitanom uzorku žena (ma koliko da je on brojan) bi moglo biti posledica smanjene iskrenosti, odnosno davanja socijalno poželjnih odgovora kod velikog broja ispitanica, što onda utiče i na iskrivljivanje 
svih dobijenih rezultata, odnosno utvrđenih nalaza o relacijama bračnog zadovoljstva i izbora strategija suočavanja sa stresom. Međutim, pošto je ispitivanje bilo na dobrovoljnoj osnovi, a nemamo uvid u broj odbijenih uključivanja u ispitivanje, moguće je i da žene koje su nezadovoljne svojim bračnim odnosom nisu bile spremne ni da se uključe u ispitivanje. Ovu dilemu bi, makar donekle, mogli ukloniti, formiranjem poduzorka iz populacije žena koje su pokrenule brakorazvodnu parnicu i ponovljenim statističkim analizama na uzorku žena među kojima bi bio podjednak broj zadovoljnih i nezadovoljnih sopstvenim bračnim odnosom.

Rezultati ranije sprovedenog istraživanja u našoj sredini (Šakotić-Kurbalija i Kurbalija, 2012) su pokazali da je globalno bračno zadovoljstvo žena značajno povezano sa njihovom percepcijom prilagođenosti partnera u različitim segmentima bračnog odnosa (gde su obuhvaćeni: dijadni konsenzus, dijadno zadovoljstvo, dijadna kohezivnost i afektivno-seksualna usaglašenost, mereni istoimenim DAS subskalama). Utvrđena je korelacija od $\mathrm{r}=0,84$ sa ukupnim skorom na DAS (Dyadic Adjustment Scale - DAS: Spanier, 1976; 1989), dok su se korelacije sa pojedinačnim subskalama kretale u rasponu od 0,63 do 0,89 . Najveća povezanost $(\mathrm{r}=0,89)$ je, očekivano, utvrđena između globalnog zadovoljstva bračnim odnosom i dijadnog zadovoljstva.

$\mathrm{Na}$ osnovu rezultata navedenog istraživanja (Šakotić-Kurbalija i Kurbalija, 2012), zaključeno je i da je najpouzdaniji prediktor bračne stabilnosti, među različitim faktorima bračnog kvaliteta, zadovoljstvo brakom i bračnim odnosom; a pri tom je utvrđeno da su globalno bračno zadovoljstvo (mereno samo jednim ajtemom) i zadovoljstvo bračnim odnosom mereno DAS subskalom (od 10 ajtema) $\mathrm{u}$ identičnoj meri povezani sa potencijalom za razvod braka $(\mathrm{r}=0,58)$.

Na podacima prikupljenim ovim istraživanjem, utvrđeno je da korelacija između globalnog bračnog zadovoljstva, merenog jednim ajtemom, i ukupnog skora na DAS dimenziji dijadnog zadovoljstva iznosi 0,88. Imajući u vidu da je ranijim istraživanjem u našoj sredini (Šakotić-Kurbalija i Kurbalija, 2012) utvrđen koeficijent korelacije od 0,89; možemo zaključiti da globalno bračno zadovoljstvo i dijadno zadovoljstvo (izraženo preko: poverenja u partnera, učestalosti bračnih konflikta, doživljaja međusobne netrpeljivosti i ličnog odnosa prema budućnosti braka) imaju visoku i stabilnu povezanost. Odnosno možemo zaključiti da je, u zavisnosti od istraživačkog cilja, nekada dovoljno postaviti jedno, umesto 10 pitanja o bračnom zadovoljstvu. ${ }^{3}$

Rezultati ranije sprovedenog istraživanja u našoj sredini (Miljanović i dr., 2013) su pokazali da strategije suočavanja sa stresom značajno doprinose globalnom bračnom zadovoljstvu žena, ali je ustanovljeni koeficijent multiple korelacije bio relativno nizak $(\mathrm{R}=0,28 ; \mathrm{p}<0,00)$. $\mathrm{U}$ tom istraživanju (Miljanović i dr., 2013) je prvo izvršena faktorska analiza na podacima prikupljenim skalom Brief COPE

Na visoku povezanost između zadovoljstva bračnim odnosom merenim samo jednim pitanjem i merenim putem više stavki su ukazali i pojedini istraživači iz Hrvatske (Obradović \& Čudina-Obradović, 2000). 
(Carver, 1997), te su definisane tri vrste strategija: Strategije usmerene na problem, Izbegavanje i Traženje i dobijanje podrške iz spoljašnje sredine; a nakon toga su, $\mathrm{u}$ višestrukoj regresionoj analizi, ovi faktori posmatrani kao prediktori globalnog zadovoljstva brakom.

Utvrđeni koeficijent multiple korelacije $\mathrm{u}$ ovom istraživanju iznosi $\mathrm{R}=0,46$ $(\mathrm{F}(14,1353)=25,37 ; \mathrm{p}<0,001)$. Međutim, treba imati u vidu da prediktorski skup obuhvata 14 varijabli, što može uticati na vrednost koeficijenta multiple korelacije. Takođe, dobijeni veći koeficijent multiple korelacije u odnosu na ranije istraživanje (Miljanović i dr., 2013) bi se bar delimično mogao objasniti i time što je izmenjena mera bračnog zadovoljstva. Skor na DAS dimenziji dijadnog zadovoljstva, koji je u ovom istraživanju predstavljao kriterijsku varijablu, pored procene globalnog bračnog zadovoljstva, obuhvata i stavke koje se odnose na: razmišljanja o razvodu, ponašanje posle svađe, poverenje u partnera, žaljenje zbog zajedničkog življenja, svađe, netrpeljivost, ispoljavanje nežnosti, stepen sreće u partnerskom odnosu, odnos prema budućnosti braka i stepen spremnosti na lično angažovanje u njegovom očuvanju; što sve zajedno predstavlja meru bračne napetosti (Dragišić-Labaš, 2008), odnosno meru distresa koji postoji u bračnom odnosu.

Kao samostalno značajni prediktori bračnog zadovoljstva pokazali su se: korišćenje emocionalne podrške, samoometanje, bihejvioralno neangažovanje, ventiliranje, instrumentalna podrška, zloupotreba supstanci, samookrivljivanje i humor. Pri tom se najznačajnim pokazalo korišćenje emocionalne podrške drugih ljudi $(\beta=0,33 ; p=0,00)$, na šta su ukazivali i rezultati ranijih istraživanja u našoj sredini (Miljanović i dr., 2013; Šakotić-Kurbalija, 2011) i u inostranstvu (Billings \& Moos, 1981; Bouchard et al., 1998; Bowman, 1990; Hamilton \& Fagot 1988; Hobfoll, et al., 1994; Stone \& Neale, 1984).

Značajno je, takođe, uočiti da: planiranje, prihvatanje, aktivno prevladavanje, poricanje, religioznost i pozitivno redefinisanje ne predstavljaju samostalno značajne prediktore bračnog zadovoljstva.

U cilju utvrđivanja strukture razlika u izboru strategija suočavanja sa stresom u odnosu na globalno zadovoljstvo bračnim odnosom, kod žena, primenjena je diskriminativna analiza, a dobijeni diskriminativni faktor je interpretiran kao pasivno-depresivno reagovanje pri suočavanju sa stresom nasuprot planiranju kako prevazići problem uz oslanjanje na emocionalnu podršku drugih ljudi. Pri tom je ustanovljeno da je za žene koje su nezadovoljne svojim bračnim odnosom karakterističnije pasivno-depresivno reagovanje pri suočavanju sa stresom, dok je ženama koje su zadovoljne svojim bračnim odnosom svojstvenije planiranje kako prevazići postojeći životni problem, i to uz oslanjanje na emocionalnu podršku drugih ljudi. Ovi rezultati su saglasni ranijim nalazima da je pribegavanje emocionalnim odgovorima na probleme i provođenje vremena u diskusiji sa prijateljima ili porodicom o problemima, povezano sa visokim zadovoljstvom bračnim odnosom, a da je korišćenje različitih ponašanja izbegavanja i udaljavanja od problema povezano sa doživljajem niskog bračnog zadovoljstva (Billings \& Moos, 1981; Hamilton \& Fagot 1988; Stone \& Neale, 1984). 
Dobijeni rezultati su u skladu i sa ranijim nalazima utvrđenim u našoj sredini (Miljanović i dr., 2013; Šakotić-Kurbalija, 2011), gde se pokazalo da je traženje emocionalne podrške i razumevanja u stresnim situacijama povezano sa visokim bračnim zadovoljstvom, dok je izbegavanje suočavanja sa stresom povezano sa bračnim nezadovoljstvom.

\section{UMESTO ZAKLJUČKA}

Iako je istraživanje bračnog zadovoljstva i faktora koji na njega utiču započeo Terman sa svojim saradnicima još tridesetih godina prošlog veka (Terman, Buttenwieser, Ferguson, Johnson \& Wilson, 1938), i do danas je objavljen impozantan broj naučnih radova na temu braka, bračnog kvaliteta, bračnog zadovoljstva, bračne (ne)stabilnosti, razvoda, te njihove povezanosti sa brojnim intrapsihičkim, interpsihičkim i sredinskim faktorima; i dalje postoji potreba za opsežnim istraživanjem u ovoj oblasti, u cilju dolaska do značajnih implikacija za unapređenje preventivnog, savetodavnog i psihoterapijskog rada.

Imajući u vidu negativan razvojni trend u brakovima u Srbiji (Jestrović, 2014; Šakotić-Kurbalija, 2013), kao i dosadašnje nalaze da bračno nezadovoljstvo nema direktan uticaj na nameru žena da potraže profesionalnu psihološku pomoć (Šakotić-Kurbalija, 2012); u daljim istraživanjima, u našoj sredini, bi bilo značajno uključiti što veći broj ispitanica koje su vrlo nezadovoljne svojim bračnim odnosom, a onda utvrditi razlike između žena koje su aktuelno u procesu dobijanja profesionalne psihološke pomoći, žena koji imaju nameru, ali još nisu tražile profesionalnu pomoć i žena koje nemaju nameru da traže profesionalnu psihološku pomoć, jer su rana i adekvatna profesionalna psihološka pomoć osnovni protektivni faktori mentalnog zdravlja (Šakotić-Kurbalija, 2012).

REZIME: Istraživačka pitanja kojima se bavi ovaj rad su: u kojoj meri različite strategije suočavanja sa stresom doprinose bračnom zadovoljstvu; i, kakva je struktura razlika u korišćenju strategija suočavanja sa stresom $u$ odnosu na globalno bračno zadovoljstvo kod žena u našoj sredini. Relacije bračnog zadovoljstva i različitih strategija suočavanja sa stresom su ispitane na uzorku od 2049 žena, koje žive na teritoriji Republike Srbije, u bračnoj ili kohabitacijskoj zajednici; starosti su od 19 do 75 godina, različitog socioekonomskog statusa. Bračno zadovoljstvo je mereno istoimenom DAS subskalom (Dyadic Adjustment Scale - DAS: Spanier, 1976; 1989), a strategije suočavanja sa stresom Brief COPE skalom (Carver, 1997). Višestrukim regresionom analizom je utvrđena statistički značajna povezanost, umerenog inteziteta $(\mathrm{r}=0,46(\mathrm{p}<0,001)$, između prediktorskog skupa varijabli, koji je činilo 14 različitih strategija suočavanja sa stresom, i bračnog zadovoljstva, kao kriterijske varijable. Kao samostalni značajni prediktori pokazali su se: korišćenje emocionalne podrške, samoometanje, bihejvioralno neangažovanje, ventiliranje, instrumentalna podrška, zloupotreba supstanci, samookrivljivanje i humor. Pri tom se najznačajnim pokazalo korišćenje emocionalne podrške 
drugih ljudi $(\beta=0,33 ; p=0,00)$. Diskriminativnom analizom je utvrđena struktura razlika u korišćenju strategija suočavanja sa stresom na osnovu koje se značajno razlikuju žene koje su globalno zadovoljne svojim bračnim odnosom i žene koje su globalno nezadovoljne svojim bračnim odnosom (koeficijent kanoničke korelacije iznosi $r_{c}=0,53 ; p=0,00$ ). Dobijeni rezultati ukazuju da je, u proseku, za žene koje su globalno nezadovoljne svojim bračnim odnosom karakterističnije pasivno-depresivno reagovanje pri suočavanju sa stresom, dok je ženama koje su globalno zadovoljne svojim bračnim odnosom svojstvenije planiranje kako prevazići postojeći životni problem, uz oslanjanje na emocionalnu podršku drugih ljudi.

\author{
Jelena Šakotić-Kurbalija \\ Marijana Miljanović \\ Dragan Kurbalija
}

\title{
RELATIONS BETWEEN MARITAL SATISFACTION AND COPING STRATEGIES
}

\begin{abstract}
SUMMARY
The main goals of this study were: to examine the extent to which different coping strategies contribute to marital satisfaction; and to determine the structure of the differences in use of the coping strategies between wives with high and low levels of marital satisfaction. The relationship between marital satisfaction and different coping strategies was tested on a sample of 2049 wives, currently living on the territory of the Republic of Serbia, in marriage or cohabitation; age from 19 to 75 , and of diverse socioeconomic status. Marital satisfaction was measured by the Dyadic Satisfaction subscale (Dyadic Adjustment Scale - DAS: Spanier, 1976, 1989), and coping strategies were measured by the Brief COPE scale (Carver, 1997). The results of the multiple regression analysis are showing statistically significant correlation of moderate intensity $(\mathrm{r}=0.46(\mathrm{p}<0.001)$ between the set of the predictor variables (i.e. 14 different coping strategies), and the level of marital satisfaction as the criterion variable. As independents significant predictors were: the use of emotional support, Self-distraction, behavioral disengagement, venting, use of instrumental support, substance use, Self-blame and humor. The use of emotional support from other people was most significant predictor of marital satisfaction $(\beta=0.33, p=0.00)$. The results of Discriminant analysis are showing statistically significant difference in the use of coping strategies between wives who are globally satisfied with their marital relationship and the wives with low levels of marital satisfaction (canonical correlation coefficient is $r_{c}=0.53 ; p=0.00$ ). The results indicate that the wives with low levels of marital satisfaction are more prone to passive-depressive reaction when faced with stress, while women who are globally satisfied with their marital relationship tend to plan a way how to overcome existing problems in life, relying more on emotional support of other people.

Key words: marriage, marital relations, marital satisfaction, coping strategies.
\end{abstract}

\section{LITERATURA}

Billings, A. G., \& Moos, R. H. (1981). The role of coping responses and social resources in attenuating the stress of life events. Journal of Behavioral Medicine, 4, 139-157.

Bodenmann, G., Lederman, T. \& Bradbury, T.N. (2007). Stress, Sex and Satisfaction in Marriage. Personal Relationships, 14, 551-569. 
Bouchard, G., Sabourin, S., Lussier, Y., Wright, J. \& Richer, C. (1998). Predictive Validity of Coping Strategies on Marital Satisfaction: Cross-Sectional and Longitudinal Evidence. Journal of Family Psychology, 12(1),112-131.

Bowman, M.L. (1990). Coping efforts and marital satisfaction: Measuring marital coping and its correlates. Journal of Marriage and the Family, 52, 463-474.

Burstein, N. R. (2007). Economic influences on marriage and divorce. Journal of Policy Analysis and Management, 26, 387 - 429.

Carver, C. S. (1997). You Want to Measure Coping But Your Protocol's Too Long: Consider the Brief COPE. International Journal of Behavioral Medicine, 4(1), 92-100.

Cohan, C. L., \& Bradbury, T. N. (1994). Assessing responses to recurring problems in marriage: Evaluation of the Marital Coping Inventory. Psychological Assessment, 6, 191-200.

Cohan, C. L., \& Bradbury, T. N. (1997). Negative life events, marital interaction, and the longitudinal course of newlywed marriage. Journal of Personality and Social Psychology, $73,114-128$.

Cohen, O., Geron, Y., \& Farchi, A. (2009). Marital Quality and Global Well-Being Among Older Adult Israeli Couples in Enduring Marriages. American Journal Of Family Therapy, 37(4), 299-317.

Dragišić-Labaš, S. (2008). Primena skale prilagođenosti dijade (bračnih partnera) u sistemskoj porodičnoj terapiji alkoholizma. Sociologija, 293-312.

Felmlee, D., Sprecher, S., Bassin, E. (1990). The Dissolution of Intimate Relationships: A Hazard Model. Social Psychology Quarterly, 53 (1), 13-30.

Fincham, F. D., \& Beach, S. R. H. (1999). Confict in marriage: Implications for working with couples. Annual Review of Psychology, 50, 47-77.

Fincham, F. D., \& Beach, S. R. H. (2010). Marriage in the New Millennium: A Decade in Review. Journal of Marriage and Family, 72, 630-649.

Hamilton, S., \& Fagot, B. I. (1988). Chronic stress and coping styles: A comparison of male and female undergraduates. Journal of Personality and Social Psychology, 55, 819-823.

Harper, J. M. Schaalje, B. G. \& Sandverg, J. G. (2000). Daily hassles, intimacy, and marital quality in later life marriages. American Journal of Family Therapy, 28(1), 1-18.

Hawkins, M.W., Carrere, S., \& Gottman, J.M. (2002). Marital Sentiment Override: Does It Influence Couples' Perceptions? Journal of Marriage \& Family, 64(1), 193-201.

Hobfoll, S.E., Dunahoo, C.L., Ben-Porath, Y., \& Monnier, J. (1994). Gender and coping: The dual-axis model of coping. American Journal of Community Psychology, 22, 49-81.

Hoffman, S. D., \& Duncan, G. J. (1995). The effect of incomes, wages, and AFDC benefits on marital disruption. Journal of Human Resources, 30, 19 - 41.

Hojjat, M. (2000). Sex differences and perceptions of conflict in romantic relationships. Journal Of Social And Personal Relationships, 17(4-5), 598-617.

Houser, R., Konstam, V., \& Ham, M. (1990). Coping and marital satisfaction in dual-career couples: Early stage dual-career couples - wives as college Students. Journal of College Student Development, 31, 325-329.

Jestrović, J. (2014). Emocionalna klima u braku - razvojna perspektiva (Nepublikovani master rad). Filozofski fakultet, Univerzitet u Novom Sadu, Novi Sad.

Kalmijn, M., Loeve, A., \& Manting, D. (2007). Income dynamics in couples and the dissolution of marriage and cohabitation. Demography, 44, $159-179$.

Lewin, A. C. (2005). The effect of economic stability on family stability among welfare recipients. Evaluation Review, 29, 223 - 240. 
Li, T. \& Fung, H. (2011). The Dynamic Goal Theory of Marital Satisfaction. Review of General Psychology, 15(3), $246-254$.

Miljanović M., Šakotić-Kurbalija J., Kurbalija D. (2013). Predikcija bračnog zadovoljstva žena na osnovu njihovih strategija suočavanja sa stresom. Treći kongres psihoterapeuta Srbije: Pripadnost $i$ različitost integracije u psihoterapiji. Beograd: 17. - 20. 10. 2013. Savez društava psihoterapeuta Srbije, Zbornik rezimea na CD-u, 81.

Obradović, J., \& Čudina-Obradović, M. (2000). Correlates of subjective global merital satisfaction in women. Društvena istraživanja, 1 (45), 41-65.

Ptacek, J. T., \& Dodge, K. L. (1995). Coping strategies and relationship satisfaction in couples. Personality and Social Psychology Bulletin, 21, 76-84.

Sabourin, S., Laporte, L., \& Wright, J. (1990). Problem solving self-appraisal and coping efforts in distressed and nondistressed couples. Journal of Marital and Family Therapy, 16, 89-97.

Šakotić-Kurbalija J., Mihić I., Kurbalija D. (2012). Povezanost ekonomskog statusa sa kvalitetom bračnog odnosa. Saopštenje na 20. Godišnjoj konferenciji hrvatskih psihologa „Psihoški aspekti suvremene obitelji, braka i partnerstava“, Dubrovnik, 07. - 10. studenog 2012. A. Brajša Žganec, J. Lopižić, Z. Penezić (eds). Knjiga sažetaka. Zagreb, Hrvatsko psihološko društvo, 259.

Šakotić-Kurbalija, J. (2011). Karakteristike bračnog odnosa i traženje psihološke pomoći (Nepublikovana doktorska disertacija). Filozofski fakultet, Univerzitet u Novom Sadu, Novi Sad.

Šakotić-Kurbalija, J. (2012). Povezanost psiholoških karakteristika braka sa namerom žena da traže profesionalnu psihološku pomoć. Godišnjak Filozofskog fakulteta, Novi Sad, 37(1), 215-226.

Šakotić-Kurbalija, J. (2013). Kvalitet i stabilnost bračnog odnosa u različitim fazama braka. Godišnjak Filozofskog fakulteta, Novi Sad, 38(2), 129-148.

Šakotić-Kurbalija, J., Kurbalija D. (2011). Povezanost potencijala za razvod braka sa različitim indikatorima ekonomskog statusa. Saopštenje na međunarodnom naučno-stručnom skupu: „,Savremeni trendovi u psihologiji“", Univerzitet u Novom Sadu, Filozofski fakultet, Odsek za psihologiju, Novi Sad. Knjiga rezimea na CD-u, 145-147.

Šakotić-Kurbalija, J., Kurbalija, D. (2012). Povezanost globalnog zadovoljstva brakom, kvaliteta bračnog odnosa i bračne stabilnosti. Psihijatrija danas, 44(2), 149-159.

South, S. J. (2001). Time-dependent effects of wives' employment on marital dissolution. American Sociological Review, 66, $226-245$.

Spanier, G. B. (1976). Measuring dyadic adjustment: New scales for assessing the quality of marriage and similar dyads. Journal of Marriage and the Family, 38, 15-28.

Spanier, G.B. (1989). Manual for the dyadic adjustment scale. North Tonowanda, New York: Multi-Health Systems.

Stone, A.A., \& Neale, J.M. (1984). New Measure of Daily Coping: Development and Preliminary Results. Journal of Personality \& Social Psychology, 46(4), 892-906.

Terman, L.M., Buttenwieser, P., Ferguson, L.W., Johnson, W.B. \& Wilson, D.P. (1938). Psychological factors in Marital Happiness. New York: Mc Graw-Hill.

Whisman, M. A. (1997). Satisfaction in Close Relationships: Challenges for the $21^{\text {st }}$ Century. U Sternberg, R.J., Hojjat, M. (Ur.). (1997). Satisfaction in close relationships (str. 385-410). New York: The Guilford Press. 


\section{PRILOZI}

Tabela 7 Matrica strukture diskriminativnog faktora

\begin{tabular}{lc}
\hline Varijabla & Korelacija \\
\hline Bihevioralno neangažovanje & .609 \\
Emocionalna podrška & -.523 \\
Zloupotreba supstanci & .486 \\
Samookrivljvanje & .384 \\
Planiranje & -.301 \\
Ventiliranje & .300 \\
Poricanje & .254 \\
Humor & -.214 \\
Pozitivno redefinisanje (reinterpretacija) & -.174 \\
Samoometanje & .155 \\
Aktivno prevladavanje & -.150 \\
Instrumentalna podrška & -.144 \\
Prihvatanje & -.044 \\
Religioznost & -.004 \\
\hline
\end{tabular}

